\title{
Assessing estrogenic activity of Nigella sativa in ovariectomized rats using vaginal cornification assay
}

\author{
Saadat Parhizkar ${ }^{1,2,3}$, Latiffah Abdul Latiff ${ }^{1,3^{\star}}$, Sabariah Abdul Rahman ${ }^{1,3}$, Mohammad Aziz \\ Dollah', Hanachi Parichehr ${ }^{4}$ \\ ${ }^{1}$ Faculty of Medicine and Health Sciences, University Putra Malaysia, Serdang 43400, Malaysia. \\ ${ }^{2}$ School of Health, Yasuj University of Health and Medical Sciences, Iran. \\ ${ }^{3}$ Institute of Biosciences, University Putra Malaysia, Serdang 43400, Malaysia. \\ ${ }^{4}$ Faculty of Science, Biology Department, Biochemistry unit, Alzahra University, Iran.
}

Accepted 14 January, 2011

\begin{abstract}
The aim of this study was to determine the estrogenic activity of Nigella sativa (NS) by vaginal cornification assay using an ovariectomized rat model. Forty ovariectomized Sprague Dawley rats, weighting 250 to $350 \mathrm{~g}$ were used in the study. N. sativa powders were administered to ovariectomized rats for 21 consecutive days at dosages of 300,600 and $1200 \mathrm{mg} / \mathrm{kg}$ respectively, and were compared with each of daily treatment with $0.2 \mathrm{mg} / \mathrm{kg}$ conjugated Equine estrogen as positive control or distilled water as negative control. Vaginal smears were taken to observe the estrogenic effect on vaginal epithelium of rats. The vaginal smear showed an atrophic pattern at baseline. The occurrence of vaginal cornification after $\boldsymbol{N}$. sativa supplementation indicated estrogenic activity of $\boldsymbol{N}$. sativa, but this effect was not as much as CEE. The most influence of $N$. sativa in vaginal cornification was observed in low dose NS that this result was in agreement with serum Estradiol level of this group. The cornified cells percentage significantly differed from control group $(\mathrm{P}<0.05)$. These data suggest that $N$. sativa possesses estrogenic function in the ovariectomized rat model which can be helpful in managing menopausal symptoms as an alternative for Hormone Replacement Therapy.
\end{abstract}

Key words: Nigella sativa, vaginal cytology assay, ovariectomized rats, estrogenic activity.

\section{INTRODUCTION}

Nigella sativa L., commonly known as black cumin seed, belongs to the botanical family of Ranunculaceae (Kamal et al., 2010). It has been used in many Middle Eastern countries as a natural remedy for 2000 years. N.sativa (NS) is an amazing herb with a rich historical and religious background (Swamy and Tan, 2001; Kamal et al., 2010). The desirable effects of N.sativa has been tested widely on cardiovascular system (Ali and Blunden, 2003; Najmi et al., 2008; Qidwai et al., 2009; Tasawar et al., 2011) immune system (Al-Ghamdi, 2001; Al-Naggar et al., 2003; Alsaif, 2008) and digestive system (Mahmoud et al., 2002; Abdel-Sater, 2009; Hassan et al., 2011) as well as homeostasis (Houcher et al., 2007; Najmi et al., 2008; Abdel-Sater, 2009; El-Bagir et al.,

${ }^{\star}$ Corresponding author. E-mail: latiffah.latiff@gmail.com. Tel: +603-89472537. Fax: +603-89450151.
2010; Tasawar et al., 2011). As a traditional medicine, $N$. sativa (Black seed) increases milk production and promotes menstruation in the female, but the effects of $N$. sativa on reproductive organs have not been clarified and particularly no scientific research was found on its effect on female reproductive system. It is therefore, necessary to determine if $N$. sativa does have any estrogenic activity on the female reproductive organ and what effect does it have. So the present study was designed to determine the estrogenic activity of short term supplementation of $N$. sativa in ovariectomized rats' using vaginal cornification assay.

\section{MATERIALS AND METHODS}

Plant materials

$N$. sativa seeds (imported from India) were purchased from a local herb store in S erdang, Malaysia. Voucher specimens of seeds 
were kept at the Cancer Research Laboratory and the seed was identified and authenticated by Professor Dr. Nordin Hj Lajis, Head of the Laboratory of Natural Products, Institute of Bioscience, University Putra Malaysia. After cleaning the seeds under running tap water for $10 \mathrm{~min}$, they were rinsed twice with distilled water and air-dried in an oven at $40^{\circ} \mathrm{C}$ overnight. The seeds were grounded to a powder shape using an electric grinder (National, Model MX-915, Kadoma, Osaka, Japan) for $10 \mathrm{~min}$ and were mixed with rat chow pellet powder and water into different doses including 300, 600 and $1200 \mathrm{mg} / \mathrm{kg}$ body weight. Afterward, dough was baked in an oven at $40^{\circ} \mathrm{C}$ until it received instant weight.

\section{Chemicals and reagents}

Conjugated Equine Estrogen (CEE $0.625 \mathrm{mg}$ ) was purchased from Wyeth, Montreal, Canada. CEE (Wyeth Montreal, Canada), prepared in a dosage of $0.2 \mathrm{mg} / \mathrm{kg}$ (Hajdu et al., 1965; Oropeza et al., 2005; Araujo et al 2006) by dissolving it in distilled water (Hajdu et al., 1965; Genazzani et al., 2004) and was used as a positive control for comparing with the supplemented groups. Estradiol Radioimmunoassay (RIA) kit was purchased from Diagnostic Systems Laboratories (DSL), USA. All other reagents and chemicals were of analytical grade.

\section{Animals}

The protocol of the study was approved by Animal Care and Use Committee (ACUC), Faculty of Medicine and Health Sciences, University Putra Malaysia (UPM) with UPM/FPSK/PADS/BR/UUH/F01-00220 reference number for notice of approval. Forty female albino Sprague-Dawley rats weighting 250 to $350 \mathrm{~g}$ aged 4 months were supplied by animal house of Faculty of Medicine and Health Sciences, University Putra Malaysia. The animals were housed in a single temperature controlled $\left(29\right.$ to $\left.32^{\circ} \mathrm{C}\right)$ cage and 50 to $60 \%$ relative humidity in $12 \mathrm{~h}$ dark/light cycle. The animals were allowed to acclimatize for at least 10 days before the start of the experiments. The rats were fed with a standard rat chow and allowed to drink water ad libitum. All animal received human care according to the criteria outlined in the "Guide for care and use of laboratory animals" prepared by the ACUC of Faculty of Medicine and Health Sciences, Universiti Putra Malaysia and animal handling were conducted between 08.00 and 10.00 am to minimize the effects of environmental changes. Vaginal smear was also examined daily. Serum estradiol and body weight were measured at baseline (day 0 ), $11^{\text {th }}$, and $21^{\text {st }}$ days at the end of experiment.

\section{Experimental design}

In order to induce menopause and to investigate reproductive changes following supplementation with $N$. sativa, the rats were ovariectomized under a combination of xylazine and ketamine $(10+$ $75 \mathrm{mg} / \mathrm{kg}$, i.p. respectively) anesthesia. Bilateral ovariectomy was performed via a dorso-lateral approach with a small lateral vertical skin incision (Parhizkar et al., 2008). The ovariectomized animals were acclimatized at the Animal House of Faculty of Medicine and Health Sciences for one month prior to supplementation.

Ovariectomized rats were assigned into five groups (each containing 8 animals). Negative control group was given distilled water $(1 \mathrm{ml})$ as the vehicle (gavage) and the second group was treated with $(0.2 \mathrm{mg} / \mathrm{kg} / \mathrm{day})$ Conjugated Equine Estrogen (CEE) (gavage) as positive control. The third, fourth and fifth groups were supplemented with NS (300, 600 and $1200 \mathrm{mg} / \mathrm{kg}$ body weight) respectively. Supplementations with $N$. sativa, CEE and distilled water were continued for 3 consecutive weeks.

\section{Vaginal smear}

Vaginal smears were carried out to monitor cellular differentiation and to evaluate the presence of leukocytes, nucleated epithelial cells, or cornified cells. Vaginal smear samples were collected between 08.00 and 10.00 am daily. The vaginal smears were prepared by washing with $10 \mu \mathrm{l}$ of normal saline $(\mathrm{NaCl} 0.9 \%)$ and were then thinly spread on a glass slide. They were allowed to dry at room temperature and then stained using Methylene blue dripping. The slides were rinsed in distilled water after $30 \mathrm{~min}$ and allowed to dry. The smears were studied using the light microscope $(40 x)$ and the cell type and their relative numbers were recorded. Vaginal smear cell counts were performed on 100 cells randomly. The percentage of cornified cells was determined according to Terenius (1971) using the following formula:

$$
\begin{aligned}
& \text { Percentage of Cornified Cells }= \\
& =\frac{\text { Cornified Cells }}{\text { Cornified Cells }+ \text { Nucleated Cells }+ \text { Leucocytes }} \times 100
\end{aligned}
$$

\section{Blood collection}

The blood samples were collected at three different times, which were on day 0 (pre-treatment), day 11 (during treatment) and day 21 (after treatment). The rats were fasted for $12 \mathrm{~h}$ before blood collection. Prior to blood sampling, the rats were anesthetized with diethyl ether to ease handling. The blood samples were collected by cardiac puncture using 25G, 1" needle. Approximately $2 \mathrm{ml}$ of blood volume were taken and dispensed into labeled plain tubes. The blood samples were then centrifuged at $3000 \mathrm{rpm}$ for $10 \mathrm{~min}$ to separate the serum. The serum was stored at $-80^{\circ} \mathrm{C}$ until assays were carried out.

\section{Statistical analysis}

Data were expressed as means \pm standard deviation. The data were analyzed using SPSS windows program version 15 (SPSS Institute, Inc., Chicago, IL, USA). The One-way Analysis of Variance (ANOVA) and General linear Model (GLM) followed by Duncan Multiple Range Test (DMRT) were used to determine which $N$ sativa concentration shows the most significant effect. A p-value less than $0.05(P<0.05)$ was considered to be significant.

\section{RESULTS}

\section{Vaginal epithelial cell cornification}

There was no significant difference in the percentage of cornified cells between groups at baseline and results confirmed a menopausal pattern in OVX rats. However after treatment, cornification was observed in all treatment groups which was significantly different from those negative control group $(p<0.05)$ which remained in an atrophic pattern as observed in the absence of estrogen (Figures 1 - 5).

\section{Serum estradiol}

Over the period of treatment, all groups showed reduction 


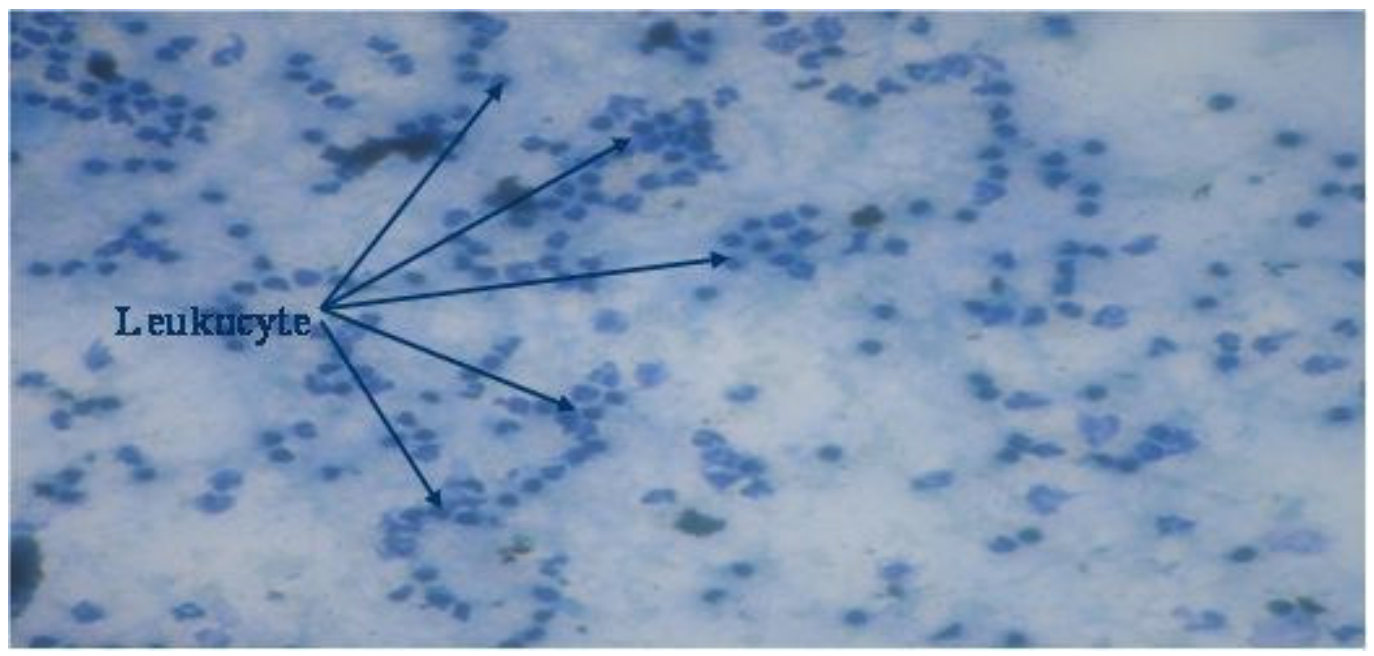

Figure 1. Vaginal smear of ovariectomized rat from control group treated with distilled water for 3 weeks. A great number of leukocytes are observed (methylene blue staining, 40x).

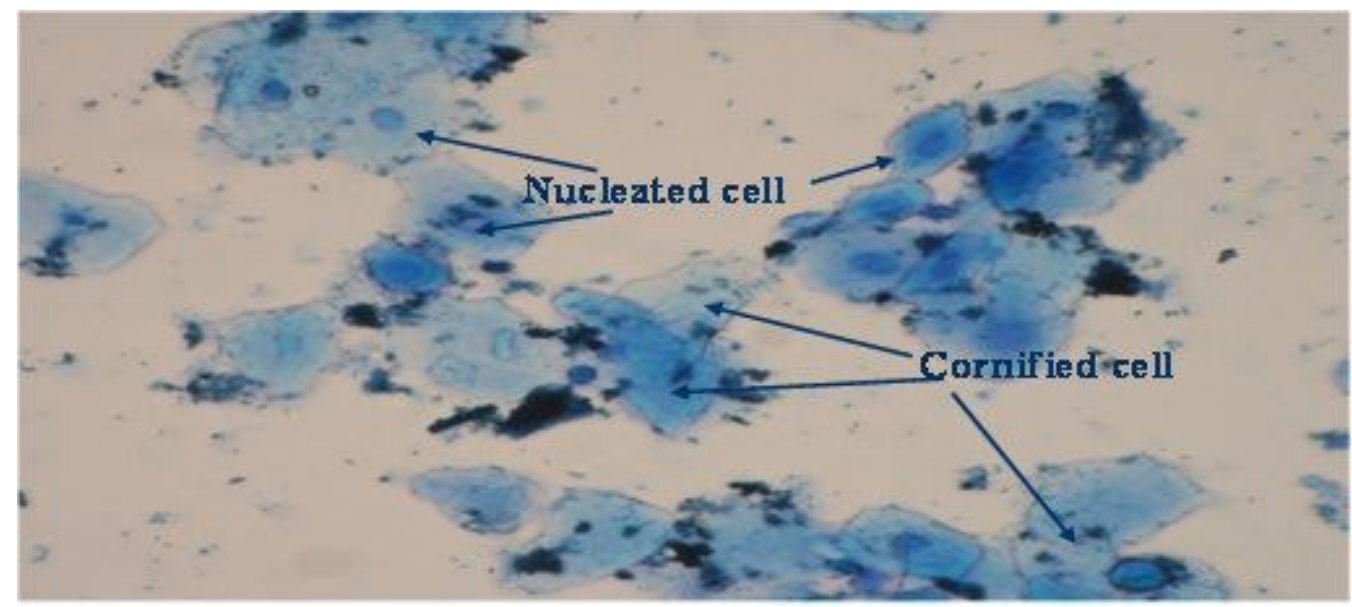

Figure 2. Vaginal smear of ovariectomized rat treated with Conjugated Equine Estrogen $(0.2 \mathrm{mg} / \mathrm{kg})$ for 3 weeks. Cornified and nucleated epithelial cells are observed (methylene blue staining, 40x).

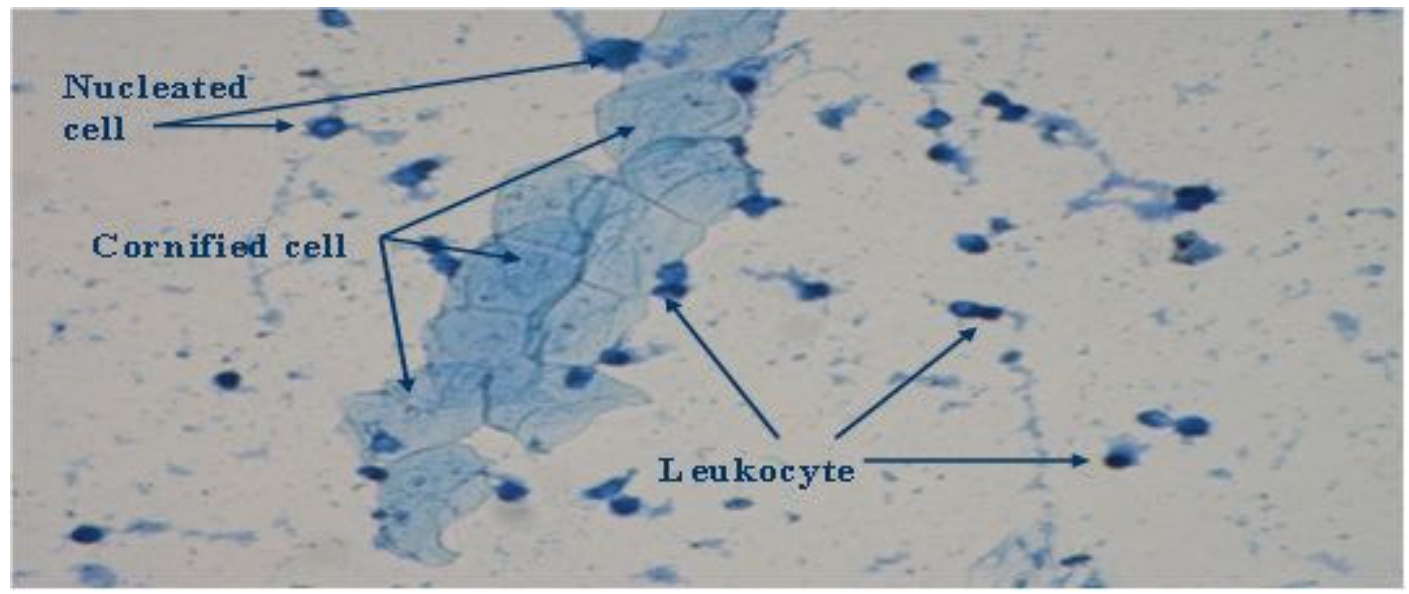

Figure 3. Vaginal smear of ovariectomized rat treated with low dose of Nigella sativa (300 $\mathrm{mg} / \mathrm{kg}$ ) for 3 weeks. Cornified, nucleated epithelial cells and leukocytes are observed (methylene blue staining, 40x). 


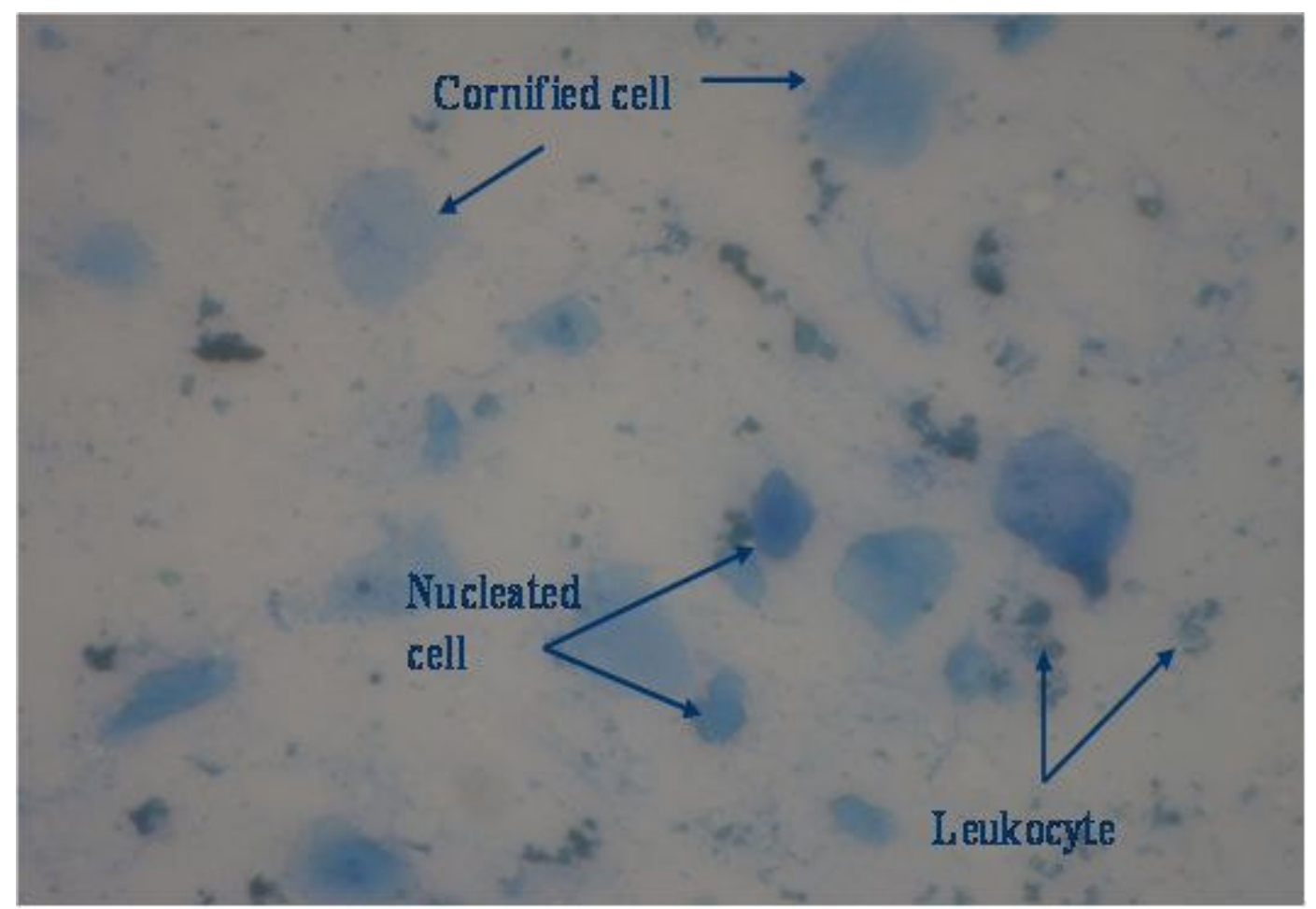

Figure 4.Vaginal smear of ovariectomized rat treated with medium dose of Nigella sativa $(600 \mathrm{mg} / \mathrm{kg})$ for 3 weeks. Cornified, nucleated epithelial cells and leukocytes are observed (methylene blue staining, $40 x)$.

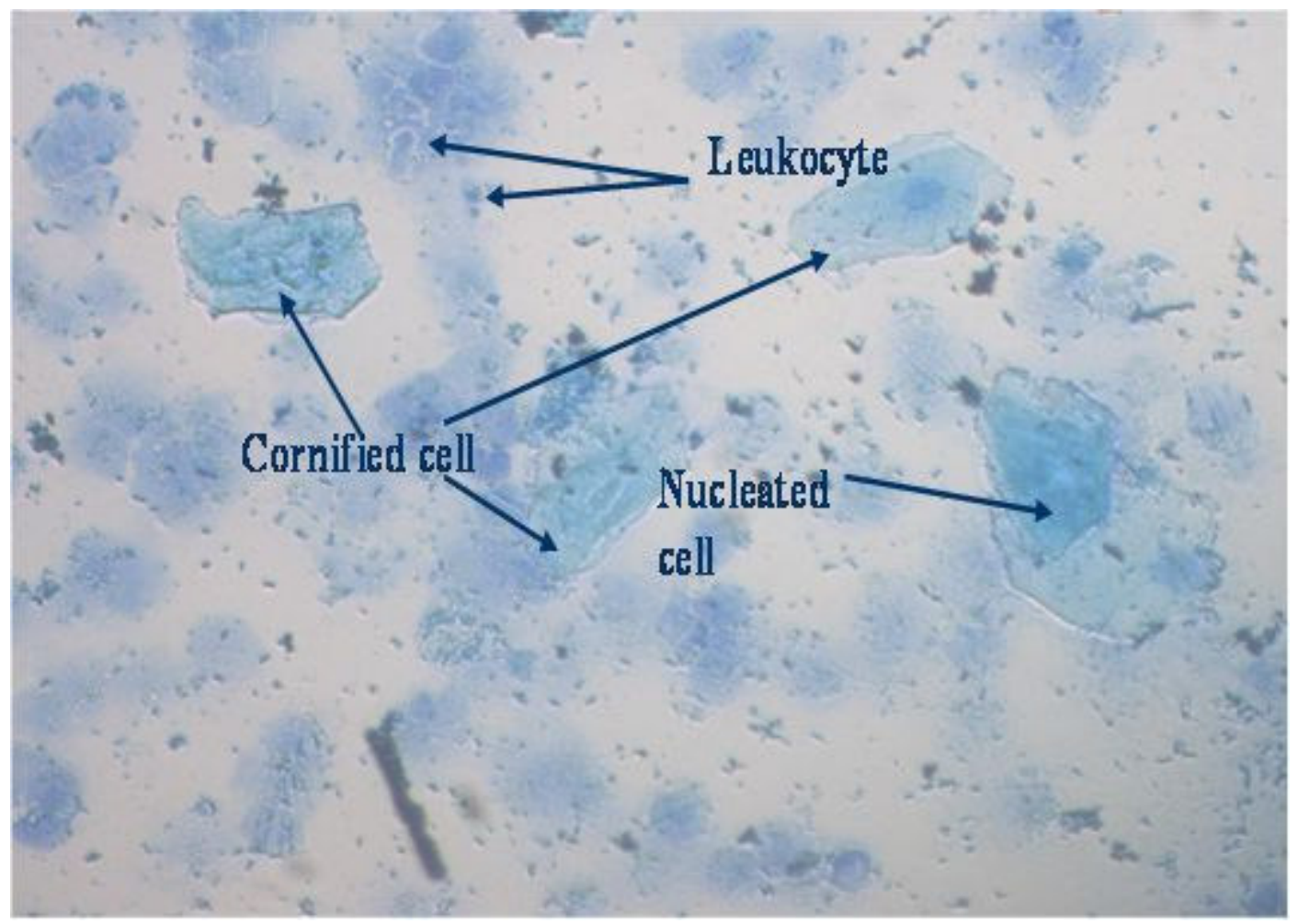

Figure 5.Vaginal smear of ovariectomized rat treated with high dose of Nigella sativa (1200 $\mathrm{mg} / \mathrm{kg})$ for 3 weeks. Cornified, nucleated epithelial cells and leukocytes are observed (methylene blue staining, 40x). 


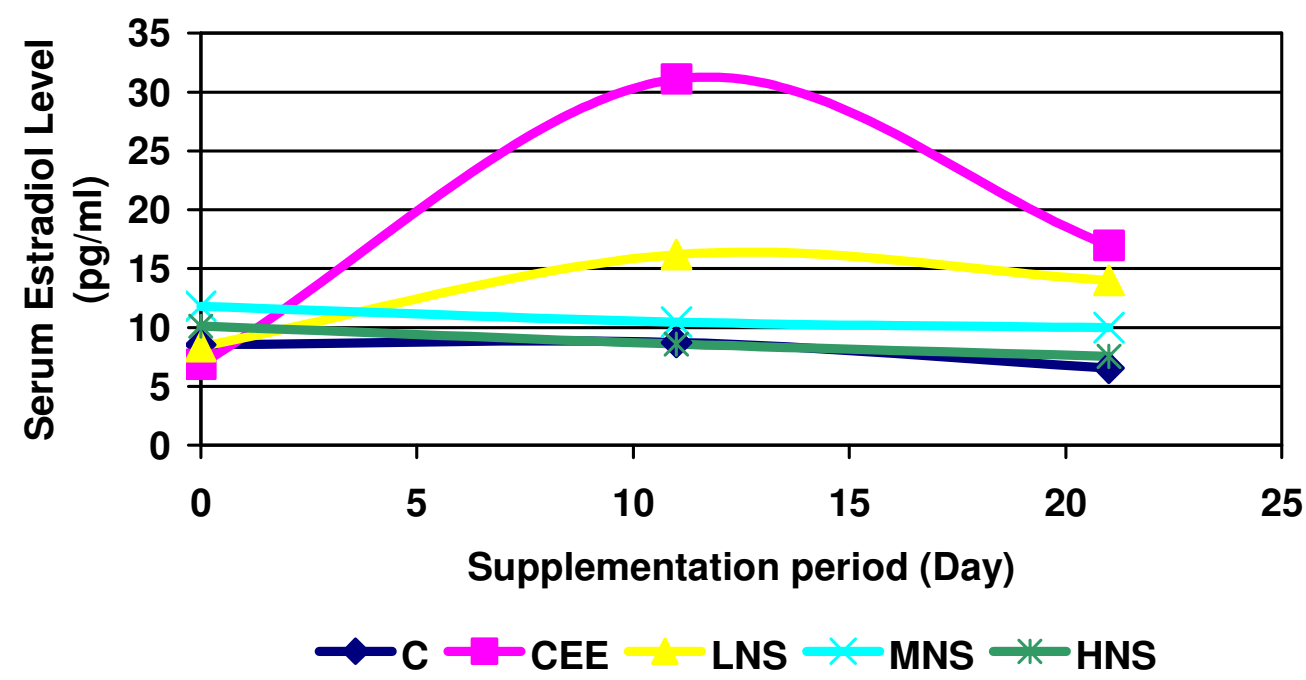

Figure 6. Changes of serum estradiol level $(\mathrm{pg} / \mathrm{ml})$ of OVX rats supplemented with various doses of Nigella sativa or Conjugated Equine Estrogen. Treatment: $\mathrm{C}=$ control $(1 \mathrm{ml}$ distilled water); $\mathrm{CEE}=$ conjugated equine estrogen $(0.2 \mathrm{mg} / \mathrm{kg})$; LNS = low dose of Nigella sativa $(300 \mathrm{mg} / \mathrm{kg}) ; \mathrm{MNS}=$ medium dose of Nigella sativa $(600 \mathrm{mg} / \mathrm{kg})$; HNS= high dose of Nigella sativa $(1200 \mathrm{mg} / \mathrm{kg})$ groups. Data expressed as mean.

in the level of estradiol except positive control (CEE) and low dose $N$. sativa supplementation which significantly increased $(p<0.05)$. OVX rats supplemented with CEE showed $353 \%$ elevation in the estradiol level in the first 10 days, afterward the estradiol level decreased, but the final level of estradiol in this group still remained $147 \%$ higher than baseline. In low dose NS, increment in serum estradiol level was observed initially, but a slight decrease was observed after the second 10 days. However the levels of estradiol in NS groups were noticeably higher than the control group (Figure 6).

\section{DISCUSSION}

The present study using ovariectomized rats provides the basis for vaginal cornification assays of $N$. sativa at the first time. Vaginal cytology assay is particularly used to determine the estrogenic activity of the synthetic estrogens, xenoestrogens (Ashby et al., 2000; Diel et al., 2000; Stroheker et al., 2003; Wuttke et al., 2003; Fusani et al., 2007) and phytoestrogens (Okazaki et al., 2002; Balk et al., 2002; Wuttke et al., 2003; Chiechi et al., 2003; Wang et al., 2003). It has been firstly used by Cook et al. (1933). It is a sensitive, simple and inexpensive method to predict the estrogenic activity. The assay can be performed in either immature or ovariectomized rodents (Ashby et al., 2000; Diel et al., 2000; Stroheker et al., 2003). In this study, N. sativa induced cornification of vaginal cells at the three doses tested $(300,600$ and $1200 \mathrm{mg} / \mathrm{kg}$ ). These results are consistent with the trend for serum estradiol level which showed more potent in low dose $N$. sativa in these rats. In the previous study
(Keshri et al., 1995) only rising in E2 level was assayed. Keshri and his colleagues (1995) reported post- coital contraceptive effect of N.sativa. On the other hand Bashandy (2007) showed that $N$. sativa oil improved reproductive performance in hyperlipidemic male rats. The effect might be due to the presence of unsaturated fatty acids that are valuable to sustain the reproductive capacity of male animals especially when they are getting older.

Other study has shown that the post coital effectiveness of $N$. sativa is roughly parallel to its estrogenecity (Keshri et al., 1995).

The mechanisms responsible for the effects of phytoestrogens are not clearly understood but there is suggestive evidence that phytoestrogens could act through two possible mechanisms namely, estrogen receptor-independent (Ginsburg and Prelevic, 2000).

Many studies have shown that phytoestrogens bind to estrogen receptors and show significant estrogenic-like effects. The considerable change in the levels of estrogen in the present study suggests that N.sativa may act both directly and indirectly on the estrogen receptors. These estrogenic activities of N.sativa could be attributed to the unsaturated fatty acid contents, which are proven to possess estrogenic effects in animals (Liu et al., 2004; Hu et al., 2007; Suzuki et al., 2008), in man and in cell cultures (Banu et al., 2006).

Vaginal cell cornification was not obvious until 5 days after beginning treatment, which indicates that the estrogenic effects of $N$. sativa may result from short-term consumption. Furthermore the recovery of rats on vaginal cytology after receiving the synthetic estrogen, conjugated equine estrogen, is also slower than the feeding of $N$. 
sativa. This might be taken as an advantage of using $N$. sativa for hormone replacement therapy compared to the synthetic estrogens when the short-term effect is needed.

The result of current study showed estrogen-like effects of $N$. sativa in some indicators such as vaginal cell cornification and blood estradiol (E2) level of OVX rats, thereby indicating the probable beneficial role for the treatment of postmenopausal symptoms.

\section{Conclusion}

This study provides novel evidence in support of continuing action of the traditional use of $N$. sativa in gynecologic disorders.

\section{REFERENCES}

Abdel-Sater KA (2009). Gastroprotective effects of Nigella Sativa oil on the formation of stress gastritis in hypothyroidal rats. Int. J. Physiol. Pathophysiol. Pharmacol., 1: 143-149

Al-Ghamdi MS (2001). The anti-inflammatory, analgesic and antipyretic activity of Nigella sativa. J. Ethnopharmacol., 76 (1): 45-48.

Ali BH, Blunden G (2003). Pharmacological and toxicological properties of Nigella sativa. Phytother. Res., 17(4): 299-305

Al-Naggar TB, Gomez-Serranillos MP, Carreto ME, Villar AM (2003). Neuropharmacological activity of Nigella sativa L. extracts. J. Ethnopharmacol., 88(1): 63-68.

Alsaif MA (2008). Effect of Nigella sativa Oil on Metabolic Responses to Prolonged Systemic Injury in Rats. J. Biol. Sci., 8(6): 974-983.

Araujo LBF, Soares JM, Simoes RS, Santos SR, Calio PL, OliveiraFilho MO, Simões MJ, Haidar MA, Baracat EC (2006). Effect of conjugated equine estrogens and tamoxifen administration on thyroid gland histomorphology of the rat. Clinics, 61: 321-326.

Ashby J, Odum J, Paton D, Lefevre PA, Beresford N, Sumpter JP (2000). Re-evaluation of the first synthetic estrogen, 1-keto-1,2,3,4tetrahydrophenanthrene, and bisphenol A using both the ovariectomised rat model used in 1933 and additional assays. Toxicol. Lett., 115: 231-238.

Balk JL, Whiteside DA, Naus G, De Ferrari E, Roberts JM (2002). A pilot study of the effects of phytoestrogen supplementation on postmenopausal endometrium. JSGI. 9: 238-242.

Banu J, Bhattacharya A, Rahman M, O'Shea M, Fernandes G (2006). Effects of conjugated linoleic acid and exercise on bone mass in young male Balb/C mice. Lipids Health Dis., 23: 5-7.

Bashandy SA (2007). Effect of fixed oil of Nigella sativa on male fertility in normal and hyperlipidemic rats. Inter. J. Pharmacol., 3(1): 27-33.

Chiechi LM, Putignano G, Guerra V, Schiavelli MP, Cisternino AM, Carriero C (2003). The effect of a soy rich diet on the vaginal epithelium in post menopause: a randomized double blind trial. Maturitas, 45: 241-246.

Cook JW, Dodds EC, Hewett CJ (1933). A synthetic oestrus-exciting compound. Nature, 131: 56-57.

Diel P, Schulz T, Smolnikar K, Strunck E, Vollmer G, Michna H (2000). Ability of xeno- and phytoestrogens to modulate expression of estrogen-sensitive genes in rat's uterus: estrogenicity profiles and uterotropic activity. J. Steroid Biochem. Mol. Biol., 73: 1-10.

El-Bagir NM, Farah ITO, Alhaidary A, Mohamed HE, Beynen AC (2010). Clinical laboratory serum Values in Rabbits Fed Diets containing Black Cumin Seed. J. Anim. Vet. Adv., 9(19): 2532-2536.

Fusani L, Seta D, Dessi'-Fulgheri F, Farabollini F (2007). Altered reproductive success in rat pairs after environmental-like exposure to xenoestrogen. Proc. R. Soc. B., 274: 1631-1636.

Genazzani AR, Stomati M, Bernardi F, Luisi S, Casarosa E, Puccetti S, Genazzani AD, Palumbo M, Luisi M (2004). Conjugated equine estrogens reverse the effects of aging on central and peripheral allopregnanolone and beta-endorphin levels in female rats. Fertil. Steril., 81(1): 757-766.
Ginsburg J, Prelevic GM (2000). Lack of significant hormonal effects and controlled trials of phytoestrogens. Lancet, 355: 163-164.

Hajdu A, Chappel CI, Rona G (1965). The influence of estrogens on scorbutic bone lesions in guinea-pigs. CMLS. 21(8): 466-467.

Hassan MI, Mabrouk GM, Shehata HH, Aboelhussein MM (2011). Antineoplastic Effects of Bee Honey and Nigella sativa on Hepatocellular Carcinoma Cells. ICT. [on Press]. published online 8 December 2010.

Houcher Z, Boudiaf Kh, Benboubetra M, Houcher B (2007). Effects of Methanolic Extract and Commercial Oil of Nigella sativa L. on Blood

Glucose and Antioxidant Capacity in Alloxan-Induced Diabetic Rats. Pteridines, 18: 8-18.

Hu Y, Hou TT, Xin HL, Zhang QY, Zheng HC, Rahman K, Qin LP (2007). Estrogen-like activity of volatile components from Vitex rotundifolia L. Indian. J. Med. Res., 126: 68-72.

Kamal A, Arif JM, Ahmad IZ (2010). Potential of Nigella sativa L. seed during different phases of germination on inhibition of bacterial growth. EJBPR. 1(1): 009-013.

Keshri G, Singh MM, Lakshami V, Kamboj VP (1995). Post-coital contraceptive effect of the seeds of Nigella sativa in rats. Indian. J. Physiol. Pharmacol., 39(1): 59-62.

Liu M, Xu X, Rang W, Li Y, Song Y (2004). Influence of ovariectomy and $17 \beta$-estradiol treatment on insulin sensitivity, lipid metabolism and post-ischemic cardiac function. Int. J. Cardiol., 97(3): 485-493.

Mahmoud MR, El-Abhar HS, Salch S (2002). The effect of Nigella sativa oil against the liver damage induced by Schistosoma mansoni infection in mice. J. Ethnopharmacol., 79(1): 1-11.

Najmi A, Haque SF, Khan RA, Nasiruddin M (2008). Therapeutic Effect Of Nigella Sativa Oil On Different Clinical And Biochemical Parameters In Metabolic Syndrome. Int. J. Diabetes Metabol., 16: 85-87.

Okazaki K, Okazaki S, Nakamura H, Kitamura Y, Hatayama K, Wakabayashi S, Tsuda T, Katsumata T, Nishikawa A, Hirose M (2002). A repeated 28-day oral dose toxicity study of genistein in rats, based on the 'Enhanced OECD test guideline 407' for screening endocrine-disrupting chemicals. Arch. Toxicol., 76: 553-559.

Oropeza MV, Orozco S, Ponce H, Campos MG (2005). Tofupill lacks peripheral estrogen-like actions in the rat reproductive tract. Reprod. Toxicol., 20: 261-266.

Parhizkar S, Rashid I, Latiffah AL (2008). Incision Choice in Laparatomy: a Comparison of Two Incision Techniques in Ovariectomy of Rats. WJAS, 4(4): 537-540.

Qidwai W, Hamza HB, Qureshi R, Gilani A (2009). Effectiveness, Safety, and Tolerability of Powdered Nigella sativa (Kalonji) Seed in Capsules on Serum Lipid Levels, Blood Sugar, Blood Pressure, and Body Weight in Adults: Results of a Randomized, Double-Blind Controlled Trial. J. Alternative. Compl. Med., 15(6): 639-644.

Stroheker T, Chagnon MC, Pinnert MF, Berges R, Canivenc-Lavier MC (2003). Estrogenic effects of food wrap packaging xenoestrogens and flavonoids in female Wistar rats: a comparative study. Reprod. Toxicol., 17: 421-432.

Suzuki KM Isohama Y, Maruyama H, Yamada Y, Narita Y, Ohta, S, Araki Y, Miyata T, Mishima S (2008). Estrogenic activities of Fatty acids and a sterol isolated from royal jelly. Evid. Based. Complement. Alternat. Med., 5(3): 295-302.

Swamy SMK, Tan BKH (2001). Extraction, Isolation and Characterization of Antitumor Principle, a-hederin from the seeds of Nigella sativa. Planta Med., 67: 29-32.

Tasawar Z, Siraj Z, Ahmad N, Lashari MH (2011). The Effects of Nigella sativa (Kalonji) on Lipid Profile in Patients with Stable Coronary Artery Disease in Multan, Pakistan. PJN. 10 (2): 162-167.

Terenius $L$ (1971). The Allen-Doisy test for estrogens reinvestigated. Steroids. 17: 653-661.

Wang XJ, Dyson MT, Jo Y, Eubank DW, Stocco DM (2003). Involvement of 5-lipoxygenase metabolites of arachidonic acid in cyclic AMP-stimulated steroidogenesis and steroidogenic acute regulatory protein gene expression. J. Steroid. Biochem. Mol. Biol., 85: $159-166$

Wuttke W, Jarry H, Becker T, Schultens A, Christoffel V, Gorkow C, Wuttke SD (2003). Phytoestrogens: endocrine disruptors or replacement for hormone replacement therapy, Maturitas. 44: S9S20. 